\title{
Professionelle og medarbejderrepræsentanter - nye roller i arbejdsmiljøarbejdet
}

\author{
Seim, Rikke; Møller, Niels; Limborg, Hans Jørgen
}

Published in:

Tidsskrift for Arbejdsliv

Publication date:

2016

Document Version

Publisher's PDF, also known as Version of record

Link back to DTU Orbit

Citation (APA):

Seim, R., Møller, N., \& Limborg, H. J. (2016). Professionelle og medarbejderrepræsentanter - nye roller i arbejdsmiljøarbejdet. Tidsskrift for Arbejdsliv, 18(1).

\section{General rights}

Copyright and moral rights for the publications made accessible in the public portal are retained by the authors and/or other copyright owners and it is a condition of accessing publications that users recognise and abide by the legal requirements associated with these rights.

- Users may download and print one copy of any publication from the public portal for the purpose of private study or research.

- You may not further distribute the material or use it for any profit-making activity or commercial gain

- You may freely distribute the URL identifying the publication in the public portal

If you believe that this document breaches copyright please contact us providing details, and we will remove access to the work immediately and investigate your claim. 


\title{
Professionelle og medarbejderrepræsentanter - nye roller i arbejdsmiljøarbejdet
}

\author{
Rikke Seim, Niels Møller \& Hans Jørgen Limborg
}

Denne artikel ${ }^{1}$ bygger på en kortlægning af udviklingen i arbejdsmiljøarbejdet i 60 danske virksomheder. Projektet belyser forskellige tilgange, 'arbejdsmiljøprofessionelle' anvender i virksomhedernes arbejdsmiljøarbejde. De arbejdsmiljøprofessionelle er, i modsætning til medarbejderrepræsentanter i arbejdsmiljøorganisationen, ansat til at håndtere og koordinere arbejdsmiljøarbejdet og til at sikre tilgang til arbejdsmiljøfaglig viden. Denne rolle udfyldes meget forskelligt. Artiklen introducerer tre forskellige tilgange til rollen som arbejdsmiljøprofessionel: 'systembyggeren', 'den procesorienterede' og 'den driftsorienterede'. Til disse tre tilgange er tilknyttet forskellige forståelser af institutionen 'arbejdsmiljøorganisationen' og forskellige samarbejdsrelationer til den lovbestemte arbejdsmiljøorganisation.

\section{Virksomhederne og medarbejderrepræsentation}

R eguleringen af arbejdsmiljøet i Danmark Rhar siden arbejdsmiljølovens vedtagelse i 1975 været funderet på den grundtanke, at kernen i virksomhedernes arbejdsmiljøarbejde skal være et formaliseret, internt samarbejde mellem arbejdsgiver og arbejdstagere.

Inden for industrien har der siden 50 'erne været regler for etablering af sikkerhedsudvalg, men med bekendtgørelsen om virksomhedernes sikkerheds- og sundhedsarbejde fra 1974 blev Sikkerhedsorganisationens (herefter benævnt $\mathrm{SiO}$ ) rolle og opbygning præciseret således, at alle virksomheder med over 10 ansatte skulle oprette en SiO. Hermed blev medarbejdernes grundlæggende ret til at vælge repræsentanter til at deltage i arbejdsmiljøarbej- det og varetage medarbejdernes interesser i forhold til arbejdsmiljøforhold stadfæstet. $\mathrm{SiO}$ og de valgte medarbejderrepræsentanter var i næsten fire årtier rammen for det interne arbejdsmiljøarbejde. I $2010 \mathrm{kom}$ der imidlertid en ændring af bekendtgørelsen om virksomhedernes sikkerheds- og sundhedsarbejde, som blandt andet betød, at $\mathrm{SiO}$ skiftede navn til Arbejdsmiljøorganisationen (herefter AMO). Denne lovændring er bredt blevet italesat som AMO-reformen.

Den såkaldte AMO-reform åbnede for en mere fleksibel organisering af det interne samarbejde om sikkerhed og sundhed (BEK nr. 1181). Det blev op til virksomhederne selv at bestemme struktur, størrelse og samarbejdsform i den interne arbejdsmiljøorganisation. Endnu et element i AMO-reformen var udfasningen af kravet om daglig sikkerhedsleder. 
Grundtanken med denne ændring af lovgivningen fra en regelbaseret regulering af organiseringen af arbejdsmiljøarbejdet til en mere målstyret og fleksibel regulering er at sikre, at arbejdsgiverne har frihed til at vælge den tilgang, der passer virksomheden bedst. Et væsentligt argument var udredninger og evalueringer, der viste, at virksomhederne havde bevæget sig væk fra den typiske industrielle virksomhedsstruktur mod en langt større diversitet og kompleksitet i virksomheds- og organisationsformer (Arbejdsmiljørådet 2009).

EU's rammedirektiv fra 1989 stiller med artikel 7 et krav til medlemsstaterne om at sikre, at

"hvis en leder ikke kan give de nødvendige beskyttelsesforanstaltninger og forebyggende foranstaltninger på grund af manglende kompetent personale $i$ virksomheden og/eller institutionen, skal arbejdsgiveren henvende sig til kompetente eksterne personer eller serviceorganer." (EU 1989)

Arbejdsgiveren er således, ifølge EU-direktivet, forpligtiget til at sikre, at virksomheden har adgang til arbejdsmiljømæssig viden. Dette krav om adgang til arbejdsmiljømæssig viden er gennem tiden blevet adresseret på forskellig vis.

I den danske regulering om $\mathrm{SiO}$, var der frem til 2010, koblet en række krav til at sikre adgang til viden. SiO's medlemmer skulle gennemføre en grundlæggende arbejdsmiljøuddannelse på fem dage, og op til 2001 skulle en stor del af arbejdsmarkedet indgå i en aftale om adgang til arbejdsmiljøekspertise (AM-ekspertise) fra en bedriftssundhedstjeneste. Med AMO-reformen lempedes kravene til grunduddannelse til blot tre dage efterfulgt af et frivilligt tilbud om årlig opfølgning, og med udfasningen af BST-pligten er adgangen til AM-ekspertise alene at finde på et privat konsulentmar- ked. Mulighederne for at arbejdsgiverne har adgang til arbejdsmiljømæssig viden, er således også blevet langt mere fleksible, men forudsætter en aktiv vurdering af behovet og en beslutning om at vælge, hvordan der skabes adgang til en sådan viden.

\section{Virksomhedernes adgang til arbejdsmiljøfaglig viden}

Der har gennem årene været udviklet en række initiativer og institutioner til at støtte det interne arbejdsmiljøarbejde. Det drejer sig primært om tilbud om uddannelse, formidling og information samt tilgang til rådgivning og vejledning. Ud over de obligatoriske uddannelsesprogrammer for medarbejderrepræsentanter og ledere tilbyder arbejdsmarkedets parter og en række private konsulenter kurser og temadage rettet mod at opkvalificere og ajourføre virksomhedernes arbejdsmiljøaktører. Formidling og information varetages primært af Branchearbejdsmiljørådene (BAR'ene), der gennem en bred vifte af medier tilbyder branchespecifik viden om arbejdsmiljø og lovkrav. Arbejdstilsynet har suppleret dette arbejde ved at udsende vejledninger tilknyttet bekendtgørelser, der med praktiske råd kan understøtte virksomhedernes arbejdsmiljøarbejde. Rådgivning og vejledning tilbydes af en række private aktører. Kun i de tilfælde, hvor Arbejdstilsynet udnytter muligheden for at påbyde rådgivning, stilles der krav til, at rådgiverne opfylder kravene til at kunne opnå en autorisation som arbejdsmiljørådgiver (BEK nr. 65, 2013, § 1, stk. 2). Gennem de senere år er der desuden, inden for byggeriet og i den kommunale sektor, opstået rådgivningstjenester, som er etableret gennem et partssamarbejde (for eksempel Bam-bus).

En række forskningsinstitutioner bidrager med en forskningsbaseret viden om, hvordan man kan overvinde arbejdsmiljø- 
problemer og udvikle forebyggelsesstrategier. Denne forskning ligger til grund for størstedelen af de informationer og den rådgivning, der tilbydes virksomheder og institutioner (Arbejdsmiljøforskningsfonden 2006).

Den mest omfattende støtte fra arbejdsmiljøprofessionelle til arbejdsmiljøorganisationen var lanceringen af Bedriftssundhedstjenesten, der trådte i kraft med arbejdsmiljøloven af 1977. Gradvist blev flere og flere arbejdspladser medtaget i denne ordning, der skulle sikre danske virksomheder adgang til arbejdsmiljøfaglig viden. Den danske Bedriftssundhedstjeneste (BST) udvikledes som et professionelt arbejdsmiljørådgivningssystem, men adskilte sig fra mange andre landes rådgivningssystemer ved primært at ansætte teknikere, ergonomer og senere psykologer, mens sundhedsfagligt uddannet personale som læger og sygeplejersker spillede en mindre rolle (Kabel m.fl. 2007). BST-ordningen blev argumentet for, at EU-kravet om adgang til arbejdsmiljøfaglig viden blev imødekommet i Danmark.

I 2001 blev reglerne om obligatorisk tilknytning til BST afskaffet, og ordningen blev udfaset over de næste syv år. Resultatet var, at en stor del af de fagfolk, som udgjorde den største gruppe af 'professionelle' specialiseret i arbejdsmiljø, fandt anden beskæftigelse, mange uden for arbejdsmiljøfeltet, men en del fandt antageligt arbejde som interne arbejdsmiljøprofessionelle (Kabel m.fl. 2007; Arbejdsmiljørådgiverne 2011). Det blev således muligt for virksomheder, der ønskede at ansætte en arbejdsmiljøprofessionel, at finde relevante ansøgere. Men det var nu overladt til virksomhederne selv at vurdere behovet for arbejdsmiljøekspertise, at finde professionel støtte til at vurdere arbejdsforhold, udvikle forebyggende strategier og være i stand til at forstå og omsætte regulering og krav fra kunder mv. til praktiske løsninger (Limborg \& Petersen 2008; Kabel m.fl. 2007). Der mangler forskning og dermed viden om, hvordan udviklingen af det frie konsulentmarked på arbejdsmiljøområdet afspejler sig i virksomheders og institutioners arbejdsmiljøarbejde. Anden forskning peger på, at betydningen af 'at have styr på arbejdsmiljøet' er vokset i kraft af, at dokumentation af et godt arbejdsmiljø får en øget betydning som et markedsparameter (Aldrich m.fl. 2010; Fabricius m.fl. 2015).

Vores antagelse er, at virksomhedernes brug af ekstern ekspertise i forhold til arbejdsmiljø er blevet begrænset efter BSTudfasningen. Samtidigt antager vi, at de to forhold, at arbejdsmiljøet har fået øget ledelsesfokus som markedsparameter, og at der har været adgang til at ansætte arbejdsmiljøprofessionelle, har betydet, at mange virksomheder vælger at ansatte egne arbejdsmiljøeksperter.

AMO-reformen kan potentielt påvirke både medarbejderrepræsentanternes rolle i det interne arbejdsmiljøarbejde og virksomhedernes adgang til arbejdsmiljøfaglig viden. Virksomhedernes reaktion på lovændringerne i AMO-reformen er undersøgt i "AMO-forskningsprojektet" 2 , der ser på udviklingen i virksomheders arbejdsmiljøarbejde i perioden 2011-2016. I dette projekt blev en stor gruppe interne medarbejdere med ansvar for arbejdsmiljø - der ofte omtalte sig selv som 'arbejdsmiljøprofessionelle' - interviewet. De gav os en første antydning af, at vores antagelse om en voksende gruppe er rigtig, samt at deres rolle repræsenterer en vigtig udvikling af virksomhedernes arbejdsmiljøarbejde.

Formålet med denne artikel er, på baggrund af data fra AMO-forskningsprojektet, at give et første bidrag til at undersøge, hvilke roller sådanne interne 'arbejdsmiljøprofessionelle' udfylder; hvordan rollen varetages, og hvilken tilgang til arbejdsmiljø- 
arbejdet det vidner om. Vi fokuserer særligt på, hvordan rollen som 'arbejdsmiljøprofessionel' udspilles i relation til det formaliserede arbejdsmiljøarbejde i AMO og de medarbejdervalgte arbejdsmiljørepræsentanter (AM-repræsentanter).

\section{Arbejdsmiljøaktører eller præ- professionalitet}

Når vi vælger at betegne arbejdsmiljømedarbejderen som en 'intern arbejdsmiljøprofessionel', bringer vi os selv i et dilemma, da der bag begrebet 'professionel' allerede ligger nogle antagelser om, hvilke drivkræfter der kan være medvirkende til at skabe udviklingen af faglighed og i sidste ende en profession. Forskningen i professioner udspiller sig mellem to poler. Den ene opfattelse ser professionerne som skabt af, at det er lykkedes for en faggruppe at indgå en 'social kontrakt' med samfundet ved at påtage sig ansvaret for, at specifikke arbejdsopgaver løses etisk forsvarligt og med en faglig høj standard, mod at få retten til at udøve professionen (Dale \& Helleshøj 1999). Den anden opfattelse tager udgangspunkt $i$, at en profession eksisterer i kraft af, at den har et vidensmonopol, som bliver fastholdt ved at definere indholdet i professionsuddannelserne og ved at give kandidater her fra en eksklusiv ret til professionsudøvelsen (Hjort 2004).

I vores undersøgelse af den gruppe af 'nye' arbejdsmiljøprofessionelle vi har mødt i vores casestudier, ville det være relevant at afdække tendenser til, at de føler sig som del af en 'faggruppe', og om de beskriver deres egen faglighed i relation til bestemte uddannelser, opfattelser og metodiske tilgange. Vi har desværre ikke i dette projekt spurgt direkte til dette, men vi har i vores efterfølgende læsning af interviewene kunne identificere sådanne opfattelser gennem deres præsentation af egen praksis. Vi vil derfor i vores analyse søge efter tendenser til, at denne gruppe åbner for potentialer til at blive en profession, i form dannelse af vidensmonopoler og forestillinger om eksklusivitet i udøvelsen af opgaven.

I det følgende vil vi først redegøre for metoden bag AMO-projektet og dernæst redegøre for de resultater, vi fandt fra de 60 casestudier omkring de arbejdsmiljøprofessionelles opgaver og roller. Derefter vil vi diskutere de mulige betydninger af disse fund.

\section{Metode}

Empirien i denne artikel stammer fra forskningsprojektet AMO, der undersøgte udviklingen af arbejdsmiljøarbejdet i danske virksomheder i perioden efter AMO-reformen i 2010/2011 og frem til 2015. Undersøgelsen var udformet som et eksplorativt, 'multiple case-studie' (Maaløe 2002; Yin 2009) og bestod af to faser.

\section{Kriterier for udvælgelse af cases}

60 danske virksomheder indgik i projektet. De 60 virksomheder dækkede arbejdsmarkedet bredt. De kom fra fem sektorer: bygge/anlægsbranchen, omsorgssektoren, servicesektoren, industri og vidensarbejde. Fra hver sektor udvalgtes 12 virksomheder på baggrund af deres besvarelser af de kvantitative kortlægninger af virksomhedernes arbejdsmiljøindsats (VAI 2012) og virksomhedernes arbejdsmiljø og helbred (AH 2012), der løbende udføres af Det Nationale Forskningscenter for Arbejdsmiljø (NFA 2015). De 12 virksomheder var fordelt med tre virksomheder fra hver af fire grupper i en firfeltstabel efter, om de svarede henholdsvis positivt eller negativt om eget arbejdsmiljø og positivt eller negativt om eget arbejdsmiljøarbejde. Virksomheder med 35 eller flere medarbejdere deltog i projektet, hovedparten af de deltagende 
virksomheder havde mellem 50 og 300 ansatte. Forskergruppen var opdelt i fem undergrupper, der hver arbejdede med en sektor. Dataindsamlingsmetoderne bestod af kvalitative interviews, udført med en struktureret interviewguide, strukturerede gruppeinterview med fokus på udviklingen af arbejdsmiljøarbejdet, observationer fra virksomhedsrundgange og deltagelse i møder, i arbejdsmiljøgrupper og udvalg samt relevant skriftligt materiale. I alle virksomheder blev ledere og AM-repræsentanter interviewet. I de virksomheder, hvor der var ansat arbejdsmiljøprofessionelle til at varetage dele af arbejdsmiljøarbejdet, blev disse også interviewet. Vi havde som udgangspunkt ikke de arbejdsmiljøprofessionelles rolle i fokus, men spurgte i alle de tilfælde, hvor der var en sådan, om deres egen opfattelse af rollen, deres faglige baggrund og om deres centrale opgaver ift. samarbejde med og udvikling af AMO. Desuden indgik der i interviewet en 'netværkskortlægning', hvor den interviewede blev bedt om at tegne det netværk angående arbejdsmiljøvaretagelsen, vedkommende indgik i.

I denne artikel anvender vi det samlede datamateriale (caserapporter, observationsnoter og interviewreferater) fra de 60 casestudier, udført i 2012/2013, til at beskrive et øjebliksbillede af de arbejdsmiljøprofessionelle, som vi mødte dem i denne periode.

\section{Dataanalyse}

Vores data blev opsummeret i 60 standardiserede case-rapporter, baseret på citater fra interviewpersonerne og deskriptive notater. I alle rapporter indgik en vurdering af omfanget af professionalisering af arbejdsmiljøarbejdet. Den byggede på de interviewede arbejdsmiljøprofessionelles beskrivelse af organisering, egen uddannelsesbaggrund, egne opgaver og baggrund for at udføre dem. Case-rapporterne blev kodet og blev gennem fælles tolkningsseminarer i forsker- gruppen analyseret for fælles mønstre og forskelle i virksomhedernes arbejdsmiljøarbejde. Efterfølgende blev alle case-rapporter reviewet af forskere fra andre 'sektorgrupper'. Analysetilgangen er inspireret af 'grounded theory' (Corbin \& Strauss 1994; Glaser \& Strauss 2009), hvor forskellige mønstre/ temaer i datasættet blev identificeret, som repræsenterer forskellige mønstre i ledelsen af arbejdsmiljø i danske virksomheder. I alt identificerede forskerholdet otte overordnede mønstre: ledelsesmæssige forandringer, engagement $i$ arbejdsmiljøarbejde, 'regulative drivers', ledelsessystemer, integration af arbejdsmiljø i det daglige arbejde, stratificeret arbejdsmiljøarbejde, strømlining af arbejdsmiljøarbejdet og professionalisering af arbejdsmiljøarbejdet. Disse temaer er uddybet $i$ en tidligere artikel (Seim m.fl. 2014a). I denne artikel ser vi nærmere på det sidstnævnte tema, 'professionalisering af arbejdsmiljøet', og fokuserer på at identificere mønstre omkring denne professionalisering', i form af den rolle og de opgaver, som de arbejdsmiljøprofessionelle udfylder samt hvordan denne rolle indvirker på det formaliserede arbejdsmiljøarbejde. Vi har derfor genbesøgt interviewene og i de tilfælde, hvor der indgik arbejdsmiljøprofessionelle, har vi anvendt deres beskrivelser af deres egen rolle og vurdering af samarbejdet med andre aktører, der bl.a. fremgår af netværkskortlægningen. De interviewede beskrev kun i få tilfælde selv deres praksis som en 'rolle'. Vi har i vores analyse af deres redegørelse for deres arbejdspraksis opgjort, hvilke opgaver de varetog, hvordan de så deres opgave knyttet til kerneopgaven, og hvordan de opfattede deres relation til den formaliserede AMO, herunder AM-repræsentanter og ledere med AM-ansvar.

Som nævnt havde den grundlæggende analyse af vores data ikke som udgangspunkt det formål at identificere de professionelles roller. Identifikationen af disse er 
fremkommet efter færdiggørelse af dataindsamlingen gennem en eksplorativ analyse af materialet sideløbende med projektets andre analyser.

I analysen af de 60 cases kunne vi identificere nogle mønstre i, hvordan rollen som arbejdsmiljøprofessionel blev varetaget og defineret. Disse mønstre har vi fået uddybet yderligere ved at vende tilbage til interviewene med de personer der angav, at de som en del af deres ansættelse udførte arbejdsmiljøarbejde. I vores data indgik en 'netværksanalyse', hvor de interviewede arbejdsmiljøprofessionelle udarbejdede en grafisk illustration af det netværk, de betjente sig af i deres arbejde. Dette har vi bl.a. anvendt til at anskueliggøre relationen mellem de arbejdsmiljøprofessionelle, de valgte AM-repræsentanter og lederne.

Vi mener, at vi med udgangspunkt i de 60 cases har et tilstrækkeligt grundlag til at kunne identificere tre generelle tilgange i de professionelles praksis, men vi har afstået fra at kvantificere vores fund, da nogle cases viste sig som repræsentanter for to eller endda tre forskellige tilgange til egen praksis, ligesom der i nogen cases ikke optræder egentlige professionelle. Derfor kan vi ikke sige noget om omfanget af udbredelsen af de tre tilgange. Vi har derfor også undladt at lave en optælling af antallet af cases på de tre tilgange.

\section{Resultater}

Et tydeligt mønster i datasættet var betydningen og omfanget af det professionelt ledede arbejdsmiljøarbejde, det vil sige de opgaver, som blev udført af arbejdsmiljøprofessionelle - i modsætning til det arbejdsmiljøarbejde, der blev gennemført i samarbejdet i AMO. I mere end tre fjerdedele af virksomhederne var arbejdsmiljøet ledet af en medarbejder, som var ansat til netop dette formål. Denne iagttagelse gjor- de vi efter den første analyse af data, da vi ikke som udgangspunkt havde valgt at fokusere på denne gruppe. Denne gruppe medarbejdere havde typisk titlen 'arbejdsmiljøkoordinator' eller 'arbejdsmiljøleder' og var ofte placeret i en stabsfunktion i organisationen. Det er disse medarbejdere, som vi i denne artikel refererer til som 'arbejdsmiljøprofessionelle'. I datamaterialet identificerede vi en række forskelle $i$, hvordan rollen udfyldes. Nogle arbejdsmiljøprofessionelle arbejdede fuldtid med arbejdsmiljøopgaver, mens andre også var ansvarlige for andre funktioner, for eksempel kvalitets- og miljøledelse etc.

I forhold til varetagelse af rollen var der en klar opdeling: Nogle beskrev deres rolle som interne arbejdsmiljøkonsulenter, hvis service skulle efterspørges af andre i organisationen, som enhver anden stabsfunktion, mens andre så sig selv som proaktive og opsøgende i deres tilgang til arbejdsmiljøet.

I forhold til opgaven beskrev nogle arbejdsmiljøprofessionelle, at de varetog størstedelen af såvel de strategiske som de driftsmæssige arbejdsmiljøopgaver. I de andre organisationer beskrev de arbejdsmiljøprofessionelle, at de udelukkende udførte strategiske opgaver og bevidst ikke arbejdsmiljømæssige driftsopgaver. I de sidste tilfælde så den arbejdsmiljøprofessionelle sin opgave og rolle som at støtte og facilitere arbejdsmiljøorganisationen samt at støtte AM-repræsentanterne i deres arbejde.

Der var således meget stor forskel i måden, hvorpå disse medarbejdere beskrev, hvordan de udfyldte deres rolle og deres tilgang til arbejdsmiljøarbejdet. Vi kunne konstatere, at der er en sammenhæn mellem den rolle, de beskrev og deres placering i organisationen, deres uddannelsesmæssige baggrund og specielt deres forhold til AM-repræsentanterne og den formaliserede arbejdsmiljøorganisation.

Nogle arbejdsmiljøprofessionelle så sig 
selv som en stabsfunktion med en bred vifte af opgaver. De beskrev en funktion, hvor de selv var den centrale varetager af viden og handling over for arbejdsmiljøorganisationen, medarbejdere og ledere. En status, der syntes afgørende for deres egen opfattelse af deres rolle i virksomheden. I samarbejdet med denne type professionelle varetog AM-repræsentanterne alt overvejende den formelle rolle at repræsentere medarbejderne i AM-udvalget, men med begrænsede beføjelser og opgaver i forhold til arbejdsmiljøet.

Andre arbejdsmiljøprofessionelle så sig som proaktive og beskrev deres rolle som støttende ift. AMO. De var dermed afhængige af, at der i AMO var beslutningskraft til at gennemføre de undersøgelser og forbedringer, som de selv bragte i forslag.

For at illustrere de mønstre og forskelle, som vi identificerede i de arbejdsmiljøprofessionelles tilgang til opgaven, har vi identificeret tre dominerende tilgange til opgaven, som de arbejdsmiljøprofessionelle på de 60 virksomheder indtager. Vi har ladet os inspirere af en tilsvarende udvikling af en typologi for AM-repræsentanter (Harris m.fl. 2012).

Vi betegner de tre dominerende tilgange til opgaven som henholdsvis 'systembyggeren', 'den procesorienterede' og 'den driftsorienterede'. I nogle tilfælde afspejlede den arbejdsmiljøprofessionelles beskrivelse af egen praksis direkte en specifik tilgang, men i mange tilfælde var den arbejdsmiljøprofessionelles praksis associeret til to eller i enkelte tilfælde tre tilgange.

De tre tilgange er beskrevet i relation til de arbejdsmiljøprofessionelles praksis og opgavefokus og deres relation til AMO i tabel 1.

Tabel 1. De arbejdsmiljøprofessionelles tilgange og deres relation til arbejdsmiljøorganisationen og AMreproesentanterne på baggrund af deres egne beskrivelser af opgave og rolle

\begin{tabular}{|c|c|c|}
\hline & $\begin{array}{l}\text { Praksis, opgavefokus og tilknytning til } \\
\text { kerneopgaven }\end{array}$ & $\begin{array}{l}\text { Relation til AM-repræsentanter og } \\
\text { arbejdsmiljøorganisationen }\end{array}$ \\
\hline Systembyggeren & $\begin{array}{l}\text { - Regulering og krav til formalisering (APV, } \\
\text { kortlægning m.m.) } \\
\text { - Holde Arbejdstilsynet i skak } \\
\text { - Systemer som mål og argument i sig selv } \\
\text { - Ses typisk i virksomheder med stor grad af } \\
\text { formalisering af fx kvalitetsprocedurer og } \\
\text { styring af drift }\end{array}$ & $\begin{array}{l}\text { AM-repræsentanter og arbejdsmiljøorganisa- } \\
\text { tionen er den professionelles værktøj til at sikre } \\
\text { implementering og drift af systemer }\end{array}$ \\
\hline Den procesorienterede & $\begin{array}{l}\text { - Afdækning af medarbejdernes opfattelse af } \\
\text { arbejdet og trivsel } \\
\text { - Skabe organisatorisk ro } \\
\text { - Tillid og samarbejde } \\
\text { - Ses typisk i virksomheder og institutioner } \\
\text { med mange relationsopgaver som fx pleje og } \\
\text { omsorg }\end{array}$ & $\begin{array}{l}\text { AM-repræsentanter og arbejdsmiljøorganisa- } \\
\text { tion opfattes som samarbejdspartnere andre } \\
\text { gange som objekter }\end{array}$ \\
\hline Den driftsorienterede & $\begin{array}{l}\text { - Sikre produktion og drift } \\
\text { - Opfylde krav fra marked og samarbejdspart- } \\
\text { nere } \\
\text { - Kundekrav } \\
\text { - Opbygning af positivt image } \\
\text { - Ses typisk i virksomheder med stort omfang af } \\
\text { kundestyring og store krav til fleksibilitet }\end{array}$ & $\begin{array}{l}\text { AM-repræsentanter og arbejdsmiljøorgani- } \\
\text { sation betragtes af nogle som midler til at } \\
\text { forbedre eller opretholde driften. Andre opfat- } \\
\text { ter arbejdsmiljørepræsentanter og arbejds- } \\
\text { miljøorganisationen som forhindringer, som } \\
\text { repræsenterer et formalistisk system. }\end{array}$ \\
\hline
\end{tabular}




\section{Systembyggeren}

Den første og mest udbredte tilgang blandt de arbejdsmiljøprofessionelle var 'systembyggeren'. Denne tilgang fandt vi inden for alle fem sektorer. De tydeligste eksempler så vi blandt bygge og anlæg samt i industrivirksomhederne. Tilgangen var karakteriseret ved, at arbejdsmiljøproblemer og forebyggelsestiltag håndteredes gennem en systematisk tilgang til arbejdsmiljøarbejde. Systembyggeren fandt faglig stolthed i selv at udvikle og vedligeholde arbejdsmiljøsystemer og ved at implementere deltaljerede procedurer, fx i samarbejde med kvalitetsprocedurer samt ved at holde styr på ændringer i lovgivningen. Arbejdet var ofte organiseret i en årlig cyklus, og systembyggeren trivedes med strukturer fra certificerede arbejdsmiljøledelsessystemer såsom OHSAS 18001. Systembyggeren motiveredes af krav til strukturelle ændringer og forebyggelse gennem at forberede virksomheden på inspektion og kontrol, mens medarbejdernes trivsel sjældent optrådte som et argument eller mål for systembyggerens opgaver.

Systembyggeren benyttede som udgangspunkt lovens krav eller retningslinjer fastsat $i$ arbejdsmiljøsystemer som argumenter for prioriteringer i diskussioner med ledelsen eller medarbejderne. For systembyggeren var AMO og AM-repræsentanterne et 'middel' til at sikre implementering og drift af arbejdsmiljøsystemet. AM-repræsentanterne og resten af AMO blev ikke anset som en vigtig aktør at involvere i selve udviklingen af systemer og procedurer, da systembyggeren så sig selv som en stabsfunktion med hovedansvaret for at 'have styr på' de procedurer og den overordnede styring af arbejdsmiljøet fx i forhold til eksterne parter såsom Arbejdstilsynet eller auditører knyttet til et certificeringsorgan. AMO og AM-repræsentanterne blev derfor opfattet som værktøjer, som systembyggeren kunne anvende til at implementere og vedligehol- de de nødvendige systemer. Størstedelen af de arbejdsmiljøprofessionelle vi betegnede som 'systembyggere' var organisatorisk tilknyttet kvalitetsafdelinger og den mere overordnede stabsledelse med ansvar for personaleudvikling og kvalitetsprocedurer.

Argumenterne for at varetage sin opgave med denne tilgang hentede 'systembyggerne' ofte i en opfattelse af, at de bedst kunne forebygge problemer ved at forholde sig til de arbejdsmiljøproblemer, der opstod, gennem at skabe klare retningslinjer og regler og ved at sætte ind, hvor de fandt manglende kontrolprocedurer. Deres forståelse af problemer knyttede sig til regler, der ikke blev overholdt, i langt højere grad end til de sundhedsmæssige konsekvenser et dårligt arbejdsmiljø måtte have. 'Systembyggerne' havde ofte implementeret arbejdsmiljøledelsessystemer fx certificeret efter OHSAS 18001 eller lignende med principper for en systematisk gennemgang af arbejdsprocesser og procedurer.

\section{Den procesorienterede}

Den anden tilgang blandt arbejdsmiljøprofessionelle var 'den procesorienterede'. Egenskaber fra denne tilgang blev også identificeret i alle sektorer. Denne tilgang var dog mest markant blandt arbejdsmiljøprofessionelle i omsorgssektoren, servicesektoren og i den offentlige sektor. Den procesorienterede tilgang så vi ofte blandt arbejdsmiljøprofessionelle, der havde særligt fokus på interpersonelle relationer og håndtering og forebyggelse af psykiske arbejdsmiljøproblemstillinger.

Den procesorienterede tilgang var karakteriseret ved at være motiveret af medarbejdernes trivsel og aktiv medarbejderinddragelse. Målene for indsatserne formuleredes ofte med udgangspunkt i menneskelige værdier eller personalepolitik. Den procesorienterede beskrev fx initiativer for at opbygge den sociale kapital (Hasle \& Møl- 
ler 2008) internt i organisationen gennem iværksættelse af interventioner og forandringsprocesser designet til at styrke tillid, retfærdighed og samarbejdskapacitet. Den procesorienterede arbejdsmiljøprofessionelle opfattede medarbejderinddragelse i forandringsprocesser som et formål i sig selv. De beskrev ofte et tæt samarbejde med personaleledelsen, personaleafdelinger og HR, i enkelte tilfælde var de arbejdsmiljøprofessionelle organisatorisk placeret i sådanne afdelinger.

Den procesorienterede tilgang betragtede AM-repræsentanterne og AMO som essentielle samarbejdspartnere. Endvidere opfattede den procesorienterede arbejdsmiljøprofessionelle AM-repræsentanterne som ambassadører, der kunne sikre kommunikation og afstemning mellem medarbejderne og AMO. De procesorienterede arbejdsmiljøprofessionelles problemforståelse knyttede sig til situationer og rammer, hvor ledere og medarbejdere ikke var i stand til at håndtere eksisterende arbejdsmiljøproblemer. Arbejdsmiljøproblemet i sig selv var ikke i fokus, det var processen og rammerne for løsningen af problemet. AM-repræsentanterne blev ikke blot set som samarbejdspartnere, men også som repræsentanter for den gruppe af medarbejdere, der var 'objekter' for de initiativer og udviklingsprocesser, som AM-repræsentanterne selv vælger at sætte i værk.

At denne tilgang typisk optrådte på arbejdspladser, der arbejder med mennesker, tillægger vi, at der er en tydelig parallelitet til den måde, man løser faglige problemer inden for denne sektor, f.eks. gennem etablering ad lærings-, pleje- eller behandlingsforløb. De professionelle betjente sig af en kombination af kvantitative værktøjer ( $f x$ trivselsmålinger) og en lang række procesorienterede indsatser, der fx fokuserede på at håndtere og forebygge konflikter, mobning og trusler.

\section{Den driftsorienterede}

Den tredje tilgang var 'den driftsorienterede' arbejdsmiljøprofessionelle. Karakteristika ved denne tilgang så vi også på tværs af de fem sektorer. De mest markante eksempler mødte vi blandt industrivirksomhederne og i bygge- og anlægsvirksomhederne. Den driftsorienterede arbejdsmiljøprofessionelle var karakteriseret ved at være pragmatisk, at fokusere på driften og på kerneopgaverne i organisationen. Arbejdsmiljøovervejelserne var, hvor det var muligt, forbundet med at fremme mulighederne for at smidiggøre driften af virksomheden. Problemforståelsen knyttede sig til arbejdsmiljøproblemer, der var hindrende for produktivitet eller markedsføring. Endvidere fokuserede den driftsorienterede tilgang på image, markedet og kundekrav, eksempelvis hvis vigtige kunder krævede certificeret arbejdsmiljøarbejde såsom OHSAS 18001.

Denne tilgang fandt legitimitet gennem en ændring i opfattelsen af arbejdsmiljøarbejdet blandt topledelsen i flere cases, hvor der var sket en forandring fra en 'gamle' ledelse til en 'ny, moderne' ledelse. Den 'nye' ledelse betragtede arbejdsmiljøet som en performanceindikator, hvilket indebar, at virksomheden skulle overholde reguleringer og være proaktiv i forhold til problemer, der kunne begrænse produktiviteten eller indebære en risiko for imagetab. Ledelsen så arbejdsmiljø som en central stabsopgave, der i lighed med fx miljøkrav, energiforbrug og hygiejnekrav primært skulle sikre, at virksomheden overholdt gældende regler.

Moderate omkostninger hæmmede ikke i denne type virksomheders overholdelse af arbejdsmiljøkrav, investeringer i værnemidler eller forebyggende værktøjer. Snarere var et højt niveau af arbejdsmiljø fremhævet i virksomhedens politik og præsentationer samt indgik som en indikator for høj kvalitet i udbud og tilbudsgivning. Denne kobling til virksomhedsdriften gav 
den arbejdsmiljøprofessionelle et relativt stort råderum.

Den driftsorienterede arbejdsmiljøprofessionelle havde et problemfokus på de situationer, hvor et dårligt arbejdsmiljø stillede sig hindrende for at opnå den ønskede produktivitet og kvalitet. De driftsorienterede havde således også øje for problemer, der knyttede sig til det psykiske arbejdsmiljø. De betragtede AMO og AM-repræsentanterne som en formel institution, der kunne sikre et godt informationsniveau og være et middel til at gennemføre tiltag, der forbedrede eller opretholdt driften. Dog kunne det medarbejdervalgte system til tider også opfattes af den driftsorienterede arbejdsmiljøprofessionelle som en bureaukratisk institution, der potentielt kunne virke som en barriere for den effektive virksomhedsdrift fx ved unødvendig brug af tid, eksempelvis i forbindelse med lovbestemte mødeaktiviteter eller medarbejderinddragelse.

\section{Analyse og diskussion}

Vi beskrev indledningsvis, at det historiske udgangspunkt for at tale om en arbejdsmiljøprofession må søges i den faglighed og det praksisfællesskab, der udvikledes blandt de ansatte i BST. Vi anser dette fællesskab som værende væsentligt tættere på en decideret profession som arbejdsmiljørådgiver, end de arbejdsmiljøprofessionelle - de internt ansatte arbejdsmiljøspecialister, som vi gennem AMO-projektet har mødt i både offentlige og private virksomheder. Blandt vores 60 cases i AMO-projektet var der tale om en heterogen gruppe mennesker, der primært havde det tilfælles, at de i størstedelen af deres arbejdstid beskæftigede sig med arbejdsmiljøarbejde. Vi rejste spørgsmålet, om vi kunne se tendenser til en profession under dannelse, en slags præprofession. Det vil forudsætte, at gruppen er i en fase, hvor de er ved at etablere sig som profession, hvilket fx kan ske gennem tiltag fra uddannelsesinstitutioner omkring etablering af efteruddannelsestilbud målrettet denne gruppe og organisationsdannelser, eller at gruppen gennem netværk formulerer tanker om, at gruppen besidder et vidensmonopol og derigennem tilskriver sig en eksklusivitet over for andres udførelse af tilsvarende opgaver. Vi har i vores interview kun i meget begrænset omfang stødt på beskrivelser af betydningen af deltagelse i faglige netværk eller af længerevarende uddannelsesforløb. I de fleste tilfælde fik vi den opfattelse, at de arbejdsmiljøprofessionelle oplevede, at de på tværs af deres meget forskellige faglige forudsætninger var rustet til at udfylde opgaven, sådan som de selv og virksomheden - havde defineret den. Vi ser ikke tendenser til, at der fra denne gruppe kan forventes initiativer til at skabe en profession. De gav dog udtryk for et ønske om at kunne dele viden og erfaringer med ligesindede i større omfang, end de havde mulighed for, da vi interviewede dem.

Ud fra analysen af de arbejdsmiljøprofessionelles beskrivelser af at udfylde rollen og varetage opgaverne, kan vi se, at gruppen spænder over et bredt kontinuum af opfattelser. Det er i sig selv en indikation for, at der ikke er en proces i gang, som sigter mod en fælles opfattelse af, hvordan en arbejdsmiljøprofessionel bør definere sine opgaver, sin rolleforståelse og sine kompetencebehov. Tilgangene synes i høj grad at være defineret af den konkrete kontekst, i hvilken de arbejdsmiljøprofessionelle, som vi har interviewet, har medvirket til at udvikle deres rolle. En kontekst, der defineres af virksomhedens arbejdsområde, markedsrelationer og af den organisatoriske placering og relation til andre aktører, som de arbejdsmiljøprofessionelle har.

Det er et vigtigt fund, at de tre arbejdsmiljøprofessionelle tilgange opfatter samarbejdet med den lovpligtige arbejdsmil- 
jøorganisation og de valgte repræsentanter meget forskelligt. Det peger på, at deres måde at udfylde deres rolle på afspejler forskellige holdninger til den formaliserede samarbejdsstruktur, dens formål og evne til at sikre et godt arbejdsmiljø, og dermed hvordan deres samarbejde kan udformes. Arbejdsmiljøorganisationen har historisk, og ifølge loven, bl.a. til formål at sikre, at medarbejderne inddrages i prioritering af arbejdsmiljøindsatsen - et forhold, som det tidligere er dokumenteret, varierer meget fra virksomhed til virksomhed, og derfor er afhængigt af andet end blot regler og organisatoriske strukturer (Hasle 2001).

Det har været fremhævet, at der er en risiko for, at $\mathrm{AMO}$ bliver en institution, der tages for givet, men som der ikke stilles forventninger til, eller som anses for et strategisk værktøj fra topledelsens side, og dermed havner som en sidevogn til linjeledelsen (Cutler \& James 1997; Frick \& Wren 2000; Jensen 2002). Ifølge de oprindelige studier af sidevognseffekten (Frick m.fl. 2000) skulle årsagen findes $i$, at arbejdsmiljøet ikke ansås for væsentligt af ledelsen. Den holdning afspejles ikke i vores materiale, vi har tværtimod set eksempler blandt de 60 case-virksomheder, hvor ledelsen anerkender arbejdsmiljøets strategiske betydning, om end der er forskellige argumenter for dette. Det er vores vurdering, at dette har givet grobund for fremkomsten af de arbejdsmiljøprofessionelle, der alt andet lige alene eksisterer i kraft af, at ledelsen har prioriteret at bruge ressourcerne på denne funktion. Det er mest tydeligt, hvor de arbejdsmiljøprofessionelle er bærere af den driftsorienterede tilgang, og hvor kundekrav er det fremtrædende argument, men det gælder også de to øvrige tilgange.

Når de arbejdsmiljøprofessionelles tilgange til deres rolle ligger inden for en af de tre tilgange, vi har beskrevet, mener vi, at det er et udtryk for, at styrkelsen af den lovpligtige AMO, og dermed sikringen af medarbejdernes indflydelse på arbejdsmiljøindsatsen, betyder væsentligt mindre end de forskellige drifts-, markedsmæssige- eller personaleorienterede motiver, ledelsen kan have for at prioritere at ansætte en arbejdsmiljøprofessionel. Med de roller, som de arbejdsmiljøprofessionelle indtager, er der muligheder for, at AMO's opgaver og måde at arbejde på, kan udvikles i tråd med intentionen i AMO-reformen og dermed bringe AMO væk fra sidevognsplaceringen. Men alle de tre tilgange kan også bevæge arbejdsmiljøarbejdet mod en situation, hvor de arbejdsmiljøprofessionelle kommer i opposition til AMO. Det centrale spørgsmål, vi rejste, var netop, hvordan de arbejdsmiljøprofessionelles roller udfordrer den formaliserede AMO. For at kunne svare på det, vil vi se på, hvad der kendetegner $\mathrm{AMO}$, for derved at kunne vurdere, om de tilgange, vi har sammenfattet ud fra de arbejdsmiljøprofessionelles beskrivelser af deres roller og opgaver, vil kunne udvikle sig som en del af AMO eller i opposition hertil.

\section{Arbejdsmiljøorganisationen en holdbar institution?}

Vi lagde i vores forskningsspørgsmål vægt på sammenhængen mellem de arbejdsmiljøprofessionelles rolle og opgaver og den formaliserede AMO, fordi AMO er kernen i den danske måde at regulere arbejdsmiljøet på. Udfordres det grundlag, som AMO hviler på, kan det få stor betydning for arbejdsmiljøindsatsen og reguleringen af arbejdsmiljøet. $\mathrm{AMO}$ er en institution, der gennem lovgivningen er pålagt alle arbejdspladser med mere end 10 ansatte. Ifølge loven skal den sikre, at arbejdspladsen formår at opfylde kravene til arbejdsmiljøet, og den skal sikre, at medarbejderne har indflydelse på arbejdsmiljøindsatsen (Arbejdsmiljørådet 2009).

Med reformen fra 2010 blev de formelle rammer løsnet i forhold til, hvordan AMO 
organiseres, og der blev lagt større vægt på den strategiske opgave og kompetenceudvikling. AMO er således en institution, der er under transformation, og det er derfor relevant at undersøge, hvordan den spiller sammen med de arbejdsmiljøprofessionelles varetagelse af deres opgaver. I AMOprojektets analyse (Seim m.fl. 2014b) af hvilke veje AMO kan påvirkes, har vi anskuet AMO ud fra et institutionelt teoretisk blik. På baggrund af Scott's definition af institutioner (Scott 2013) tager vi udgangspunkt i dennes teorimodel, der definerer 'Tre søjler af institutioner', som vi bruger til at beskrive og kategorisere formationen og udviklingen af en institution: "Institutions comprise regulative, normative and culturalcognitive elements that, together with associated activities and resources, provide stability and meaning to social life" (Scott 2008, 56). De tre søjler er:

- Det regulative: Omhandler institutioners evne til at tvinge og regulere adfærd.

- Det normative: Fremhæver de normative regler, der påpeger rettigheder og privilegier samt ansvar og pligter.

- Det kulturelt-kognitive: Fokuserer på de fælles opfattelser, der udgør naturen af den sociale virkelighed samt rammerne, hvorigennem mening skabes.

Betragtes AMO i dette perspektiv, har vi i AMO-forskningsprojektet, gennem en analyse af argumenterne for at bevare eller ændre AMO blandt de aktører, der optræder i de 60 case-studier, kunnet dokumentere, at den klassiske forståelse af AMO som et samarbejdssystem, hvor medarbejderrepræsentanter og ledere arbejder sammen for at sikre et sikkert arbejdsmiljø ved at balancere interessevaretagelsen mellem ledelsesretten og medarbejdernes lovfæstede indflydelse, fortsat er udbredt. I denne forståelse er AMO både lovligt, moralsk og kulturelt sanktioneret og bygger dermed på alle tre søjler.

Vi tolker den holdningsændring, vi sporer blandt lederne, fra at se AMO og arbejdsmiljøkrav som et nødvendigt onde, til prioritere at have professionel ekspertise i staben, som en ny konkurrerende forståelse af AMO, som vi omtaler som 'mainstreaming'. Denne forståelse stiller spørgsmålstegn ved den regelbaserede institution. Den 'nye AMO' er ikke i sig selv en institution i virksomheden, men må snarere ses som et udtryk for en ny-institutionalisering ud fra en generel institutionel forståelse af ledelse. Det centrale i denne forståelse er, at der ikke stilles spørgsmålstegn ved, at arbejdsmiljøet skal være i orden, kombineret med, at det bør varetages som en stabsfunktion på linje med kvalitet, hygiejne, miljø og lignende. Den nye AMO er baseret på alle tre søjler, men den statslige regulering og forhandling af interessemodsætninger er svækket, og den samfundsmæssige, markedsmæssige og offentlighedsmæssige regulering er derimod styrket.

Sammenholder vi denne udvikling med de arbejdsmiljøprofessionelles tre tilgange og deres opfattelse af AM-repræsentanter og formaliseret arbejdsmiljøarbejde, kan de tolkes som tre forskellige veje til mainstreaming af arbejdsmiljøarbejdet, der alle forrykker balancen mellem de tre institutionelle søjler.

Det centrale formål for systembyggeren er overholdelse af reguleringer; AMO og AM-repræsentanter er midler til at sikre denne overholdelse. Systembyggeren iværksætter selv arbejdsmiljøinitiativer og koordinerer AM-repræsentanternes opgaver. I nogle tilfælde håndplukker systembyggeren ligefrem AM-repræsentanter til at udføre specifikke opgaver. Hermed lægger systembyggeren vægt på institutionens regulative element, men undertrykker dens repræsentative normativitet. 
Den procesorienterede arbejdsmiljøprofessionelle ser AMO som en ramme for at opfylde virksomhedens sociale forpligtelse til at inddrage medarbejderne $\mathrm{i}$ beslutningsprocesser og argumenterer for nytteværdien i denne tilgang. Inddragelse er det normative, ikke institutionen i sig selv. Man kan derfor forestille sig en opprioritering af direkte inddragelse af medarbejdere på bekostning af den repræsentative inddragelse.

Den tredje tilgang - den driftsorienterede arbejdsmiljøprofessionelle - er i høj grad pragmatisk og fokuserer på kerneopgaven og den daglige drift i virksomheden. Overholdelse af reguleringer bliver taget for givet. I de virksomheder, hvor vi mødte den driftsorienterede arbejdsmiljøprofessionelle, så vi, at AMO opfattes som en formalitet uden nogen reelle arbejdsmiljøaktiviteter. I enkelte tilfælde er arbejdsmiljørepræsentantens arbejde end ikke associeret med arbejdsmiljø, men i stedet med kerneopgaven i virksomheden. I disse tilfælde har det regulative mistet sin betydning, og forståelsen af AM-repræsentanternes og AMO's rolle sker ud fra en kulturel-kognitiv meningsskabelse, 'hvordan gør de gavn for virksomheden'?

De arbejdsmiljøprofessionelles rolle og problemforståelse kan således udfordre det grundlag, AMO hviler på. Specielt systembyggerens og den driftsorienterede arbejdsmiljøprofessionelles forståelse af AMO og medarbejderrepræsentanternes rolle og betydning udfordrer grundlaget ved at monopolisere arbejdsmiljøaktiviteter, både på det strategiske og på det operationelle niveau. Ved at tiltage sig retten til at prioritere hvilke initiativer der skal tages, absorberer de arbejdsmiljøaktiviteter og centraliserer dem omkring dem selv. Udgangspunktet for prioriteringer bliver derfor deres egen problemforståelse og ikke medarbejdernes fælles prioritering af, hvor de oplever, der bør sættes ind. Det kan - måske utilsigtet - få den betydning, at AM-repræsentanterne enten udfylder en formel og tom rolle uden egentlig indflydelse på arbejdsmiljøaktiviteter, eller at de bruges som den arbejdsmiljøprofessionelles middel til at sikre implementering af egne agendaer. Uanset hvad, er det repræsentative element i AM-repræsentanternes rolle truet. AM-repræsentanterne får svært ved at rejse selvstændige krav til arbejdsmiljøet baseret på medarbejdernes erfaringer og ønsker og får dermed svært ved at skaffe magt bag ved selvstændige krav fra medarbejderne.

Vores data peger på, at den rolle, som de arbejdsmiljøprofessionelle indtager, konstrueres gennem forsøg på at sammenstille de forventninger, der formuleres fra ledelsen og i mindre grad fra medarbejderrepræsentanter og deres indsigt i, hvordan andre kolleger (fx fra HR) eller andre inden for deres netværk har valgt at praktisere deres funktion. Det, samtidigt med at det ofte ser ud til, at de har ganske vanskeligt ved at aflæse sådanne forventninger, da der sjældent er formuleret direkte mål med deres arbejde.

De arbejdsmiljøprofessionelle vi har mødt, kan kun betegnes som potentielle præ-professionelle, da arbejdsmiljø ikke er etableret som en egentlig profession. Vi har dog valgt at fastholde termen 'arbejdsmiljøprofessionel' i denne artikel, da vi vil undersøge, om de tendenser, vi ser, kan være starten på en mulig professionalisering.

\section{Konklusion}

Formålet med denne artikel er at undersøge den rolle, som gruppen af arbejdsmiljøprofessionelle indtager, og hvordan denne rolle påvirker det medarbejdervalgte system. Artiklen bygger på en analyse af data fra 60 case-studier på virksomheder og institutioner fra fem centrale sektorer samt giver et bud på, hvordan de arbejdsmiljøprofessio- 
nelles roller kan forklares ud fra et omfattende eksplorativt case-studie.

En foreløbig konklusion er, at rollen som 'arbejdsmiljøprofessionel' i vores materiale ser ud til at være en voksende tilgang til intern arbejdsmiljøledelse, og at denne rolle varetages og udfyldes på meget forskellige måder. Vi har i artiklen beskrevet tre fremtrædende tilgange til rollen: 'systembyggeren', 'den procesorienterede' og 'den driftsorienterede' arbejdsmiljøprofessionelle. Systembyggeren har en systematisk tilgang til arbejdsmiljøledelse, hvor implementering og vedligeholdelse af systemet er målet i sig selv, og AM-repræsentanterne er et middel til at opnå dette mål. Den driftsorienterede arbejdsmiljøprofessionelle har en pragmatisk tilgang til arbejdsmiljøledelse. Denne type af arbejdsmiljøprofessionel fokuserer vedholdende på virksomhedens kerneopgave. Dette betyder, at den driftsorienterede arbejdsmiljøprofessionelle enten har et instrumentelt syn på AM-repræsentanterne i tråd med systembyggeren, eller opfatter AM-repræsentanterne som forhindringer. Dette kan associeres til en forståelse af arbejdsmiljøområdet som et potentielt konfliktfelt, hvor medarbejderne/AM-repræsentanterne kan modarbejde de forandringer, den arbejdsmiljøprofessionelle mener, er nødvendige. Den procesorienterede arbejdsmiljøprofessionelle er motiveret af at opretholde den organisatoriske ro og af at facilitere processer, der involverer alle medarbejdere i udvikling af arbejdet. AM-repræsentanter betragtes ofte som essentielle samarbejdspartnere i forhold til opgaven med at holde ro og sikre driften, men inddragelse af medarbejderne kan lige såvel ske gennem direkte inddragelse.

Specielt systembyggeren og den driftorienterede arbejdsmiljøprofessionelle har en tendens til at absorbere alle arbejdsmiljøaktiviteter, hvilket risikerer at efterlade AM- repræsentanter med en formel rolle uden indflydelse. Den obligatoriske regulering af virksomhedernes arbejdsmiljøarbejde, gennem AMO og valgte AM-repræsentanter bygget på samarbejde og medarbejdernes deltagelse, udfordres af disse roller i arbejdsmiljøarbejdet. Funktionen som intern arbejdsmiljøprofessionel synes at være kommet for at blive, men den udfyldes med forskellige tilgange, defineret $i$ et samspil mellem virksomhedens (ledelsens) prioritering og de professionelles eksisterende faglige forudsætninger for at udfylde rollen. Den ser derfor indtil videre ikke ud til at være et erhverv eller en profession.

Hvis de eksempler, vi har set på, hvordan de arbejdsmiljøprofessionelle definerer deres rolle og opgaver, viser sig at være en generel tendens, vil det have to implikationer. For det første sker der en udvikling af ikke én, men flere forskellige praksisforståelser til opgaven som arbejdsmiljøprofessionel, illustreret ved de tre tilgange. Vi skal ikke tage stilling til, om det er problematisk. Vi kan blot konstatere, at der i de interviews, vi foretog af de arbejdsmiljøprofessionelle, $i k k e$ refereres til, at man ser sig selv som del af en gruppe ligesindede, eller at man henviser til vigtigheden af uddannelsesprogrammer, faglige sammenslutninger, samarbejde med forskning og håndslag om kvalitetsnormer, som er det en professionsdannelse skabes af.

For det andet har vi set, at en ledelsestankegang, illustreret ved driftsfokusering og systemanvendelse, har vundet kraftigt terræn i forhold til grundlaget for 'den danske model' (AM-loven) i kraft af de roller, de arbejdsmiljøprofessionelle varetager. Risikoen er en nedbrydning af AMO-institutionen gennem den ledelsesmæssige institutionalisering af arbejdsmiljøarbejdet, hvor den reguleringsmæssige og vidensbaserede arbejdsmiljøtilgang nedprioriteres eller forsvinder. 


\section{NOTER}

1 Denne artikel er støttet af midler fra Arbejdsmiljøforskningsfonden, tak for det. Ligeledes tak til forskningsassistent Stefanie Hansen.
2 Læs mere om projektet på: http://cavinet.dk/ forskningsprojekterne/udviklingen-i-virksomhedernes-arbejdsmiljoarbejde-amo/

\section{ReferenCER}

Aldrich P.T., M. Gudmundsson \& R. V. Andersen (2010): Arbejdsmiljø set med virksomhedsøkonomiske briller, i Øje på arbejdsmiljøet, november 2010. Landsorganisationen i Danmark.

Arbejdsmiljøforskningsfonden (2006): Kortloegning og analyse af dansk arbejdsmiljøforskning, rapport udgivet af Arbejdsmiljøforskningsfonden.

Arbejdsmiljørådet (2009): Afrapportering fra trepartsdrøftelser om virksomhedernes arbejdsmiljøarbejde, april 2009.

Arbejdsmiljørådgiverne (2011): Arbejdsmiljøprofessionelle i Danmark, red. Morten Bichel, redegørelse udgivet af Arbejdsmiljørådgiverne.

BEK nr. 65 af 17/01/2013: Bekendtgørelse om autorisation af rådgivervirksomheder på arbejdsmiljøområdet, Arbejdstilsynet.

BEK nr. 1181 af 15/10/2010: Bekendtgørelse om samarbejde om sikkerhed og sundhed, Arbejdstilsynet.

BSI. (1999): OHSAS 18001: Occupational Health and Safety Management System - Specification, London, British Standards Institution.

Corbin, J. \& A. Strauss (1994): Grounded theory methodology, i Handbook of qualitative research.

Cutler, T. \& P. James (1997): Moving beyond the side-car syndrome: A case of self-interest?, i New Solutions 7, 3, 46-52.

Dale, E. L. og H. Helleshøj (1999): Retningslinjer for god undervisning i sundhedsuddannelserne, i J. J. Eriksen \& L. Hounsgaard: Laering $i$ sundhedsvoesenet, København, Gyldendal Uddannelse.

EU (1989): "Framework Directive": Directive 89/391/EEC - OSH "Framework Directive",
Article 7 Protective and preventive services, 12 June 1989. https://osha.europa.eu/da/ legislation/directives/the-osh-frameworkdirective/ 1 p 6

Fabricius, K. m.fl. (2015): Arbejdsmiljøcertificeringsordninger - litteraturstudie, Arbejdstilsynet.

Frick, K. m.fl. (2000): Systematic Occupational Health and Safety Management - An Introduction to a New Strategy for Occupational Safety, Health and Well-being, i K. Frick m.fl. (red.): Systematic Occupational Health and Safety Management, Oxford, Pergamon Press, 1-16.

Frick, K. \& J. Wren (2000): Reviewing Occupational Safety and Health Management, i K. Frick m.fl. (red.): Systematic Occupational Health and Safety Management, Oxford, Pergamon Press, 17-42.

Glaser, B. G., \& A. L. Strauss (2009): The Discovery of Grounded Theory: Strategies for Qualitative Research, London, Transaction Publishers. Retrieved from: https://books.google.com/ books?id=rtiNK68Xt08C\&pgis $=1$.

Harris, L. A., K. B. Olsen \& J. W. Robyn (2012): Role typology for health and safety representatives, i Employee Relations 34, 5, 481-500.

Hasle, P. (2001): Sikkerhedsorganisationens lange vej, i Tidskrift for Arbejdsliv 3, 2, 95-110.

Hasle, P. \& N. Møller (2008): From Conflict to Shared Development: Social Capital in a Tayloristic Environment, i Economic and Industrial Democracy August 2007, 28, 401-429.

Hjort, K. (red.): De professionelle - forskning i professioner og professionsuddannelser, Frederiksberg, Roskilde Universitets Forlag, 2004. 
Jensen, P.L. (2002): Assessing Assessment: The Danish Experience of Worker Participation in Risk Assessment, i Economic and Industrial Ergonomics 29, 3, 121-31.

Kabel, A., P. Hasle \& H.J. Limborg (2007): Occupational Health Services in Denmark the rise and fall of a multidisciplinary and preventive approach, i Supporting Health at work, red. Peter Westerholm, IOSH Services Limited.

Limborg, H. J. \& J.V. Petersen (2008): Arbejdsmiløørådgivningens fremtid - set $i$ historisk lys. PAVLA projektet, TeamArbejdsliv.

Maaløe, E. (2002): Casestudier af og om mennesker i organisationer, Akademisk Forlag.

NFA hjemmeside 2015: http://www.arbejdsmiljoforskning.dk/da/arbejdsmiljoedata/virksomhedernes-arbejdsmiljoeindsats-2012-2020.

Scott, W. R. (2013): Institutions and Organiza- tions: Ideas, Interests, and Identities. Sage Publications

Scott, W. R. (2008). Lords of the dance: Professionals as institutional agents. Organization studies, 29(2), 219-238

Seim, R., S. Poulsen, \& O. Broberg (2014a): New developments in occupational health and safety management in Danish companies, i 11th International Symposium on Human Factors, Copenhagen.

Seim, R., P.L. Jensen \& N. Møller (2014b): The Development of Danish OHS Regulation Organizational Understanding and Program Theory, i 11th International Symposium on Human Factors, Copenhagen.

Yin, R. K. (2009): Case Study Research: Design and Methods, i L. Bickman \& D. J. Rog (red.): Essential Guide to Qualitative Methods in Organizational Research, 5, London, Sage Publications.

Rikke Seim, cand.polyt., ph.d., adjunkt, DTU Management Engineering e-mail:seim@dtu.dk

Niels Møller, mag.scient.soc., lektor, AAU Center for Industriel Produktion, København e-mail: nm@business.aau.dk

Hans Jørgen Limborg, cand. techn. soc., ph.d., arbejdsmiljørådgiver og arbejdslivsforsker, TeamArbejdsliv

e-mail: hjl@teamarbejdsliv.dk 